\title{
Managing Capital Market Crimes: the Role of Nigeria's Securities And Exchange Commission
}

\author{
Ahmed Aliyu \\ Department of Criminology and Security Studies, Federal University Dutse-Nigeria
}

\begin{abstract}
Capital market is a highly sensitive environment which thrives on investor confidence generated by the prevailing rules and regulating its operations. It is considered as a vital link to the growth and development of the modern national economy due to its ability to attract potential investors to the other economic subsectors. Thus, it is defined as the avenue where the wealth of a country is sold and bought through instruments known as securities or stocks which represent financial values. Recent developments within the Nigeria's capital market indicate that it is characterized by different forms of crimes which led to its collapse in 2008. This paper therefore examine the role which Nigeria's Security and Exchange Commission as the apex regulatory agency of the market plays in managing such crimes. The findings suggest that, although (SEC) has introduced several measures to curb the occurrence of crimes within the market, it needs the cooperation of other agencies whose activities are also linked to the operations of the market. This will help in the area of ensuring total compliance with sanctions and punishments so that those who are indicted are not operating in another sector of the market.
\end{abstract} Keywords: Capital market, Crimes, Managing, Nigeria, Role, Securities

\section{Introduction}

The concept of crime generally implies the violation of established rules of conduct in the society. It is a concept that is defined with high degree of consensus among criminologists as a result of its embedment in criminal law, hence its minimum meaning is considered as an act defined by law, Abdullahi (2004). Although crime is also defined from the sociological perspective, the most widely used is the legal definition provided by Tappan, (1947) as follows: "Crime is an intentional act in violation of criminal law (statutory and case law), committed without defense or excuse, and penalized by the state as a felony or misdemeanor" Tappan in Lanier and Henry, 2001:31.

However, capital market crimes are considered as business crimes which are not clearly defined like conventional or organizational crimes. Although some unethical business practices are classified as crimes, Reid (1996) explained that business activity is full of intrigues and complexities which cannot easily be defined. It is in recognition of this fact that governments all over the world created a special agency to control the activities of the market participants, especially those that run contrary to the established rules and regulations. In addition, capital market is considered as a vital component of modern global financial system in view of its role towards the economic development of a country.

Although, Nigeria's capital market like any other capital market in the world is regulated by other agencies, however, Securities and Exchange Commission (SEC) is recognized as the apex regulatory agency among them. It is against this background that this study was conducted to examine the role of which Nigeria's Securities and Exchange plays in managing crimes within it.

\section{Statement of the Research Problem And Objective}

Capital market is a specialized market or an avenue for selling and buying financial instruments such as shares, bonds, bill certificates, etc. They are being issued by corporate organizations as evidence of contract between them and the buyers to serve as security or protection of their investments in the organization. Even though Nigeria's capital market is relatively young, it is however considered to be among the emerging financial markets in the world as a result of its potentials. However, recent developments within the market show that, it is characterized by fraudulent and sharp practices resulting in its collapsed in 2008.

A recent study conducted by Aliyu (2011) reveals that among the various forms of crimes discovered in the market are; illegal sales of stocks or shares belonging to clients by stock brokers, circulation and sales of fake or non existing shares to investors by registered stock brokers, diversion/conversion of clients stock proceeds by stock brokers, insider trading, manipulation of annual accounts, deliberate withholding of share certificates by registrars, etc. The occurrence of these crimes within the market has resulted in the loss of investors' funds estimated to be in millions of dollars apart from its impact on the Nigerian economy and other social consequences. 
These crimes were committed against the fact that several regulatory institutions and measures have been put in place by the Nigerian government to ensure proper management of the market so that investors are protected from losing their funds. Among the various agencies established by the government to regulate the market, Securities and Exchange Commission (SEC) is the apex regulatory agency. Against this backdrop, the major objective of the paper therefore, is to examine its role in managing such crimes within the market considering the fact that, the recent collapsed of the market has been attributed to the existing level of crimes.

\section{An Overview of Nigeria's Capital Market}

The development of the market is dated as far back as March 1960 when the Lagos Stock Exchange was registered and incorporated under section 2 of the Lagos Stock Exchange Act 1960. However, first attempt made to control the capital market, according to Ekiran (1999), was in the early 70s when the Central Bank of Nigeria $(\mathrm{CBN})$ established the Capital Issues Committee as a department. It was charged with the responsibility of controlling new issues of securities and other major matters, especially in the primary arm of the capital market. In December 1977, it became The Nigerian Stock Exchange (NSE), with Head Office in Lagos and branches established in some of the major commercial cities of the country. At present, there are six branches of The Nigerian Stock Exchange with each branch having a trading floor. The branch in Lagos was opened in 1961; Kaduna, 1978; Port Harcourt, 1980; Kano, 1989; Onitsha, February 1990; and Ibadan August 1990; Abuja, October 1999 and Yola, April 2002.

The Exchange is the center point of the Nigerian capital market, while Securities and Exchange Commission (SEC) serves as the apex regulatory body.The Exchange, which started operating in 1961 with 19 securities listed for trading, today has 262 securities listed. The Exchange provides the avenue for trading existing securities, as well as encourages large scale enterprises to gain access to public listing. At present, it is made up of 11 Government Stocks, 49 Industrial Loan (Debenture/Preference) Stocks and 194 Equity / Ordinary Shares of Companies, all with a total market capitalization of approximately N287.0 billion, as at August 31, 1999 (Wikipedia, 2008). Most of the listed companies at the exchange have foreign or multinational affiliations and represent a cross-section of the Nigerian economy, ranging from agriculture and manufacturing to services. The Exchange also provides a mechanism for mobilizing private and public savings, and makes such funds available for productive purposes.

The market has in place a tested network of Stockbrokerage Firms, Issuing Houses (Merchant Banks), practicing corporate law firms and over 50 quality firms of auditors and reporting accountants (most of them with international links). Operations within the market are conducted at two levels, i.e. the primary and secondary markets, respectively. The primary market is where new securities are issued and the mode of offer for securities traded in this market include the offer for subscription, right issues, the offer for sales and private placement. The secondary market on the other hand is where trading in existing securities is conducted. It consists of exchange and over the counter market where securities are bought and sold after their issuance in the primary market. Major participants in the market are operators such as issuing Houses, Stock broking firms, Investors, etc., other key participants serving as regulators are Securities and Exchange Commission (SEC) which occupies the apex regulatory position, the Nigeria Stock Exchange (NSE) provides the market environment for transactions and regulation of operators through self-regulatory mechanisms. On the other hand, the Central Bank of Nigeria and the Federal Ministry of Finance provide supervisory roles by formulating periodical monetary policy guidelines, and, finally the Investments and Securities Tribunal (IST), which is a specialized court, also handles all the disputes that are referred to it by the SEC.

Although the origin of the Securities and Exchange Commission dates back to 1962, its full emergence was only actualized in 1980 under Decree No. 71 of 1979 to replace the then capital Issues Commission sequel to the recommendations of Financial System Review Committee which was set up by the federal government to review capital market activities and proffer ways of developing the market in order to cope with emergent challenges. Pursuant to the enactment of Decree No. 71 of 1979, the commission as the apex regulatory agency of the market was saddled with the responsibility of developing and regulating it in order to maintain proper ethical standards and professionalism. But unlike its two predecessors, the Commission was excised from the control of Central Bank of Nigeria but continued to receive funding from the government through the apex bank. The commission had a 12 member board of directors with CBN representative as Chairman. While other members were drawn from the Ministries of Finance, Trade and Industries, the Nigerian Stock Exchange and the Nigerian Enterprises Promotion Board; other members were nominated on the basis of individual merit.

However, Nine (9) years after the establishment of the Securities and Exchange Commission, the enabling law, Decree No. 7 of 1979, was re-enacted as SEC Decree No. 29 of 1988 with additional provisions to address observed lapses in the previous arrangement and to enable the Commission pursue its functions more effectively. To further enhance the Commission's pursuit of its objective of investor protection, a review of the capital market was carried out in 1996 by a seven - man panel headed by Chief Dennis Odife resulting in the establishment Investment and Securities Tribunal (IST) as a specialized judiciary body base on Investment and 
Securities Act No. 45 of 1999. The tribunal is an independent agency vested with the responsibility of adjudicating on disputes and controversies in capital market transactions which are referred to them by the Securities and Exchange Commission's Administrative Panel Committee (APC). The new Act which was expected to promote a more efficient and virile capital market, pivotal to meeting the nation's economic and developmental aspirations repealed the SEC Act of 1998. At the moment, the commission's powers are driven from this act which has again been reviewed, amended and subsequently passed into law in 2007.

Thus, from a staff strength of 51 in 1980, out of which seven (7) were temporarily drafted from the Central Bank of Nigeria (CBN) for a period of three years, today the commission has a total staff strength of 574 as at end of December 2011 (2011 Annual Report and Accounts). The staff members spread across the head office in Abuja and seven zonal offices at Lagos, Kano, Port Harcourt, Kaduna, Maiduguri, Onitsha and Ibadan respectively. In addition, the Commission which is recognized globally as a member of International Organization of Securities Commission (IOSCO) since 1985 is qualified as an Appendix 'A' Signatory to the IOSCO MMOU in 2006. This has helped the commission to continuously benchmark its market rules and regulations according to international standards. Among the various functions and powers of the Commission are: Determining the prices of issues and setting the basis for allotment of securities, registration of the stock exchange, or its branches, registrars, investment advisers, securities dealers and their agencies and regulating investments and securities business in Nigeria as defined in Investment and Securities Act No. 29 of 2007.

Presently, the composition and structure of the Commission is as follows:

\section{Organizational Structure of Nigeria's Securities And Exchange Commission}

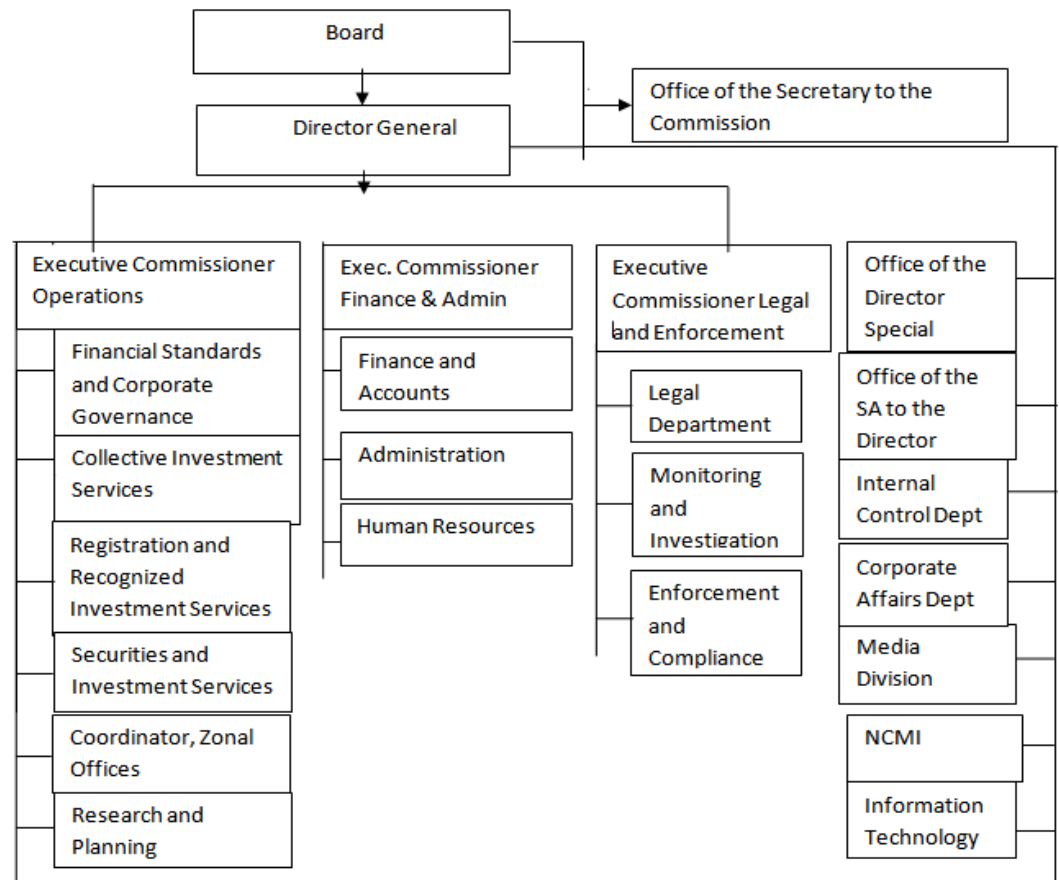

Source: Adopted from SEC Annual Reports and Accounts 2011

\section{Literature Review/Theoretical Framework}

Academic interest in economic crime, according to Larson (2004) began at the end of 1940s and early 1950s when a ground breaking research on the black market fraud connected to the ration system after World War II was conducted. However, business enterprise is a complex endeavor which flows through a spectrum of activities ranging from the most conventional to the most unconventional methods. In other words, it is a series of activities characterized by transparency, openness, honesty as well as sharp practices, greed, meanness, selfishness, etc., which often result in the circumvention of normal procedures. The complexities of Business activity means that, it is an undertaken which may either result in profit or loss depending on the ability or inability of the entrepreneur to navigate the competitive environment.

Although losses and profits are integral parts of business activities, individuals or corporate organizations detest the idea of loosing fortunes. It is therefore in an attempt to avoid losses or to maximize profits that most business men and organizations contravene the established rules and regulations governing the conduct of business affairs which are regarded as business crimes. For example, an entrepreneur whose believe is that profit or gain can be achieved through illegitimate business activity or by cutting corners can be guilty of committing what is regarded as business crime. However, Reid (1996) averse that business related crimes differ 
from conventional or ordinary crimes. For example, while Conventional crimes which include violent acts such as assault, rape, murder, as well as property related crimes such as robbery, burglary, theft etc and are usually committed by people of lower or blue-collar classes.

On the other hand, violation of law in the course of activity in a legitimate occupation entails different forms crimes which are often referred to as white- collar crimes or business world crimes. In addition, Millard (2005) also explained that unlike other crimes, economic crime is not as black and white, because they come in subtle forms, whereby even the victims may not be aware that a crime has been committed against them. For example, in investment fraud like insider trading, the perpetrators may genuinely believe that what they are doing is within the boundaries of the law or feel that everyone else is doing it and so it must be acceptable.

In Nigeria, economic and financial crimes are defined under the Economic and Financial Crime Commission Act 2002 as non-violent criminal and illicit activity committed with the objective of earning wealth illegally either individually or in a group or organized manner. These include any form of fraud, such as narcotic drug trafficking, money laundering, embezzlement, bribery, looting and any form of corrupt practices, illegal arms deal, smuggling, human trafficking and child labor, oil bunkering and illegal mining, tax evasion, foreign exchange malpractice, including counterfeiting of currency, theft of intellectual property and piracy, open market abuse, dumping of toxic wastes, and prohibited goods (Shehu 2006).

Simpson (2002) posits that in law corporations can commit the same offences as humans, therefore in deciding to criminalize a particular behavior the state should engage in victimology to identify which behavior causes the most loss and damage to its citizens. This means that regulatory agencies representing the state in overseeing the capital market need to identify the most serious crimes committed by the organizations in order to prevent future occurrence, or sanction the offenders. Moreover, Igwe (2004) assert that:

The quality of regulatory environment (the laws, regulations, interpretation of the laws and regulations as well as the mechanisms for enforcement) is a major index necessary to attract investible funds. Thus, the efficacy of the laws, improved legal processes and institutions (including the judiciary) as well as the observance and enforcement of the rule of law are imperative in surviving globalization (2004:1).

Mwenda (2006) argues that although there is no unified theory of financial services regulations, such as the capital market, the following objectives can be seen as the bases for regulation:

1. Protecting investors in order to earn their competence;

2. Ensuring that the markets operate within the concept of a fair, efficient and transparent manner;

3. Reducing systemic risk;

4. Protecting financial services business for the capital market and

5. Malpractice by some consumers, such as money laundering.

He further maintained that the overall objective of achieving the above regulatory goals is because where market abuses, such as unlawful and unauthorized disclosure, insider dealing and money laundering are effectively controlled, the prospect building both investor and consumer competence in the market becomes high.

Research conducted by Coburn (2005), revealed that corporate crimes usually occur initially where there are gaps in procedures as a result of which individuals see weaknesses in the existing system and take advantage of an opportunity that is presented to them. Thus, Codere (2006) in his work "fraud detection" explained that the reasons for committing fraud can be understood by using the "fraud triangle", which allows opportunity, pressure and rationalizations. The learned author, quoting Grabosky and Braithwaite (1987), explained that:

The opportunity for fraud arises when controls are weak and/or when an individual is in a position of trust while the pressures on those to commit fraud are often financial, unrealistic corporate targets can influence employees to commit fraud to meet targets. The rationalization for fraud often includes beliefs that the activity is not criminal, their actions are justified (Codere 2006: 351).

\section{Radical Theory}

The Radical or Critical criminological theory developed by Ian Taylor and others postulates that 'the social control of criminals is biased because criminal law focuses on behaviors in which the powerless are most likely to engage, such as public drunkenness' ('Reid, 1996:163). The class bias in law, explained Reid, is evident, because many criminal cases of the upper classes, such as financial crimes, are processed through civil and special created administrative laws instead of proper criminal justice system, such as the law courts.

Siegel (2004) explained that although there is no single view that defines Marxist criminology today, all the same their general proposition is centered on the existing relationship between the ownership and control of private property in capitalist society. For example, radical Marxists are concerned with the processes of law making, law breaking and enforcement, as well as the conflicts that arise from the economic structure within the capitalist system (Shehu 2006). 
Instrumental Marxism, which is a branch of the radical theory, postulates that the law, the State, and the ruling class are one instrument, which enables the ruling class to take advantage of other classes by determining the nature and enforcement of law. Proponents of this criminological school of thought also argued that the poor may or may not commit more crimes than the rich, but on the contrary they are often penalized more than the rich. In other words, the criminal justice system does not focus the same attention on crimes committed by the rich or the elite such as capital market crimes.

The above position by instrumental Marxism captures the prevailing relationship between modern organizations and their regulators within the neo- capitalist economic system or structure like capital market. For example, several cases of financial crimes with enormous cost or damage to the society have been or are being committed in both developed and developing countries, such as Nigeria, but yet not much is being done to persecute the offenders perhaps because of their social status within the society.

Snider (1993) argues that there are instances where many corporate crime cases are even settled before they are taken to court. Furthermore where there are efforts to show that the offenders are being prosecuted little prison time sentences or punishments are given to them. For example, the trial and convictions of Ivan Boesky and Michael Milken in the US over billions of dollars securities fraud were considered to be far less than the level of the crime they committed. Quinney (1980) opined that crimes committed by the ruling class are crimes of domination and repression, which are necessitated by the desire to protect their interest. Thus, capital market crimes resulting from the trading of financial instruments in the market can also be classified as an aspect of economic domination by the ruling class or rich people, who control economic power through the legal establishment or corporate entities.

Chambliss (1976) also asserts that many crimes are motivated by greed, self- interest and hostility generated by the capitalist system, because the members of each group employ available means and opportunities provided by their positions to commit crime. In this context, capital market crimes can also be viewed as crimes generated by, among other reasons, such as competition and profit- making.

In relating the explanations of the radical theory to the nature and prevention of crimes, such as corporate crime, it is clear that, the theory linked the crime to the issue of resource ownership and the nature of law or control mechanism in the capitalist economic system (i.e. that the law or control agencies, such as the Securities and Exchange Commission, are created to sustain the capitalist economic system). Hence, despite their existence, crimes are being committed since the punishments are considered to be far lesser than the benefits of the crimes.

Thus, while annual losses from street crimes amount to $\$ 4$ billion, losses from such crimes in USA on the other hand are more than 20 times greater. She maintained that there are numerous cases of illegal behaviors by corporations and their employees. The recent scandals by American Mortgage Savings and Loan companies are attributed to fraudulent activities, such as insider dealing, failing to disclose accurate information in accounts and racketeering, resulting in a bail out that cost US government $\$ 700$ billion, is another good example of the devastating effect of capital market crimes.

\section{Data Collection}

\section{Methodology of the Study}

The study was conducted base on qualitative research method. In particular, in-depth interview (IDI) method was adopted to generate qualitative data from the respondents, which were drawn from 4 statutory regulatory agencies and 6 other institutions whose operations have a direct bearing on the capital market. The questions on the interview guide were constructed in the English language and administered on respondents with the help of research assistants. In addition, data obtained from publications such as annual accounts, in-house journals, etc., were content analyzed to compliment the (IDI) data.

The in-depth interview was conducted on two top management staff of the SEC and one each from the NSE, the CBN, the Federal Ministry of Finance and the Investments and Securities Tribunal. Similarly, one middle management staff was interviewed from the SEC, the NSE, the CBN, the Federal Ministry of Finance, the Associations of Registrars, Trustees, Stockbrokers, Issuing Houses and the Chartered Institute of Stock Brokers.The remaining five respondents interviewed were selected from the junior staff cadre of the SEC and the NSE, while three were drawn from the SEC and two from the NSE. Here, two factors were taken into consideration, i.e. the relevance of each institution in the capital market regulation and the duties of each respondent within the respective agency.

\section{Population of the Study}

The population of this study was drawn from 4 major regulatory agencies, which are the Securities and Exchange Commission, the Nigerian Stock Exchange, the Central Bank of Nigeria and the Federal Ministry of Finance. Other respondents were selected from the Investment and Securities Tribunal, as well as other professional associations of the capital market operators, such as the Association of Registrars, Trustees, 
Stockbrokers, the Chartered Institute of Stockbrokers and Issuing Houses in view of their knowledge and understanding of Capital Market operations.

\section{Sample Size and Sampling Procedure}

For the purpose of this study, a total of 11 respondents were drawn to generate data. The size cut across the four Capital Market regulatory agencies, which are the SEC, NSE, CBN, and the Federal Ministry of Finance, as well institutions whose operations have a direct bearing on the market, such as the Investment and Securities Tribunal, the Association of Registrars, Trustees, Stockbrokers, the Chartered Institute of Stockbrokers and Issuing Houses. Furthermore, secondary sources of information (published case files, annual accounts and reports) were consulted to compliment the data generated from the IDI.

The selection was made taking into account factors such as the size of the organization or agency, its staff strength, and the role played by the organization within the capital market. Therefore, since the SEC is larger and the apex of all the regulatory agencies, three (3) respondents were selected from it, while two (2) respondents were selected from the NSE in view of their low staff strength as compared to SEC. Similarly, one (1) respondent each were selected from the Federal Ministry of Finance, Investments and Securities Tribunal, Chartered Institute of Stockbrokers, Associations of Registrars, Trustees, Stockbrokers and Issuing Houses in view of their staff strengths and roles in the market. Thus, the total sample size of 11 respondents was used for the study.

The sampling procedure for the study is a non-probability sampling method. This is because the sample was drawn based on the availability of the respondents, taking into consideration their knowledge of the research topic, hence the use of a purposive or judgmental sampling procedure.

\section{Discussions Of Findings}

The outcome of data generated in the course of the study reveals that, although Securities and Exchange Commission generally regulate Nigeria's capital market operations through different mechanism, however, crimes that are committed in the market are specifically managed under the departments of monitoring and investigation, and that of enforcement and compliance. For example, majority of the respondents interviewed explained that the Commission as the apex regulatory agency of the market keeps abreast of the happenings within it through constant monitoring and surveillance undertaken by monitoring and investigation department. The commission in this regard, monitors and captures all the transactions on the floor of the Stock exchange on a daily basis and uses the information gathered by its Stock Exchange Unit to analyse the market activities; and if there is any abnormal or un-usual trend, it swings into action immediately before any major damage is done.

Similarly, issues relating to market participants who commit crimes are handled by the commission through its enforcement and compliance department as explained by the respondents in the following manner. Once the Commission receives a report or complaint from an investor or clients, it swings into action by investigating the allegations. The responsibility of investigating complaints, according to the respondents lay on the Commission's investigation and enforcement department. For instance, when a complaint is received, the investigation and enforcement department writes to the party or company that is alleged to have committed the offence, indicating that an allegation or complaint has been made against it by XYZ Company or person for committing a particular offence. After receiving a response from the accused person or company, the commission subsequently requests for an all party meeting with a view to resolving the matter. However, if after the all party meeting the issue at stake is not resolved, the commission will resort to the next line of action, i.e. the investigation department will now refer the case to the enforcement department, stating that XYZ Company has committed a particular offence and should therefore be punished in line with the commission's prescribed rules and regulations.

Another way in which erring market operators are sanctioned by the commission is through the process of restitution. This means that when a broker as an offender is confirmed to have illegally sold a client shares and diverted the proceeds, the commission ensures that all the accruing interests and benefits relating to the stocks are paid in full to the rightful beneficiary at the prevailing Central Bank interest rate of transaction. The reason for this policy is that the offender is not allowed to enjoy the benefits of the fraud proceeds in any way. In addition, the Commission usually notify the investments and security tribunal (IST) to place a freeze order on the account and if there is enough reason to suspect that the accused is likely to run away from the country, the commission notifies all the relevant security agencies such as the State Security Services, the Nigerian Immigration Service and the police that $\mathrm{Mr} \mathrm{X}$ of so-so company is alleged to have committed a financial crime and is being investigated; therefore, he/she should not be allowed to travel out.

The commission also has an in-house administrative proceeding committee that adjudicates on reported cases of market infractions by operators. Available data from some of the reviewed commission's publications between the periods of $2000-2007$ reveals through its administrative proceeding committee, the commission 
was able to handle various complaints from the investors and other related agencies. Although there are no complete records on all the proceedings of the committee from 2000 - 2004, however, administrative hearing committee of the commission was able to handle 850 cases within the same period. However, between the periods of 2005 to 2007, there are significant or sufficient data, which reveal that the commission was able to handle a total number of 7155 complaints on various aspects of the capital market operations, as shown in the table below.

Number of Cases and their Standing before Administrative Proceeding Committee

\begin{tabular}{|c|c|c|c|c|c|c|}
\hline Year & $\begin{array}{l}\text { The Number of } \\
\text { complaints }\end{array}$ & $\begin{array}{l}\text { Against } \\
\text { Registrars }\end{array}$ & $\begin{array}{l}\text { Against } \\
\text { Stockbrokers }\end{array}$ & $\begin{array}{l}\text { Against } \\
\text { Individual/bank } \\
\text { (Money } \\
\text { laundering) }\end{array}$ & $\begin{array}{l}\text { Closed } \\
\text { Cases }\end{array}$ & $\begin{array}{l}\text { Pending } \\
\text { Cases }\end{array}$ \\
\hline 2005 & 3060 & 1735 & 1161 & 164 & 224 & 2836 \\
\hline 2006 & 2133 & 1072 & 912 & 149 & 166 & 1967 \\
\hline 2007 & 1962 & 1006 & 956 & - & 962 & 1000 \\
\hline
\end{tabular}

Source: Annual Reports and Accounts of SEC (2005-2007)

The table shows that out of the 7155 cases received by the SEC, 1355 were closed, while 5803 were pending. The closed cases were those that were amicably resolved between the parties involved, or sanctioned by the commission. The pending cases, according to respondents from the commission are usually carried forward to the next year, because of the sensitive nature of the complaints, which require thorough investigations that are often time consuming, before arriving at decisions.

\section{Summary/Conclusion}

The study revealed that Securities and Exchange Commission as the apex regulatory agency of Nigeria's capital market plays some significant role in managing crimes within the market. The commission is able to do so through its monitoring, surveillance, evaluation, enforcement, compliance, restitution and other regulatory mechanisms. These processes are coordinated by different departments in harmony with one another in line with the overall policy objectives of the commission. For example, market surveillance, according to the research findings, plays a vital role in preventing crimes within the market. This is because it provides the basis for regulators to act immediately, so that crimes are nipped in the bud before they occur. The introduction of the above preventive measures by the commission further strengthens the position of Kramer (1993), who argued that when law enforcement is weak or lax the condition for organizations to commit crime is maximized.

However, although the findings revealed that the commission has put in place measures to prevent crimes in the market, there is the need to improve and create more innovations with a view of bringing the crimes to minimal level. This is owing to the fact that Nigeria`s capital market like any other cannot be completely free from crimes, since the nature of its trading or activities are related to financial securities which requires different measures from that of conventional crimes.

\section{Recommendations}

1. Monitoring of the market should be given more priority by the commission through constant surveillance in order to prevent the operators from committing crimes.

2. The commission should ensure strict adherence to the rules of corporate governance within the market.

3. The commission should engage in more public enlightenment activities. This will help the public understand the operations of the market and its dynamics. Particularly, issues relating to buying and selling of stocks.

4. Finally, the commission as the apex regulatory agency of the market should solicit for the cooperation of other regulatory agencies in order to ensure those who are punished by the commission or any regulatory agency for committing crime are not allowed to operate in another sub- sector of the market.

\section{References}

[1]. Abdullahi, S. (2004). Crime and Crime opportunity techniques in Nigeria Banking Industry. Seminar Paper presented on crime prevention, modern method of Security Management in Banks, Organized by Finance in Format Dev. Co. Abuja.

[2]. Aliyu, A. (2011). The Nature and Prevention of Corporate Crime in Nigeria's Capital Market (Unpublished master's thesis). Bayero University, Kano, Nigeria.

[3]. Braithwaite, J. (1989): Criminological Theory and Organizational Crime Justice Quarterly, Vol. 6 No.3.

[4]. Chambliss, W. J. and Mankoff, M. (1976). Who's Law? What Order? New York: John Wiley \& sons.

[5]. Coburn, N.F. (2006): Corporate Investigation. Journal of Financial Crime Vol. 13 No.3.

[6]. Coderre, D. (2006). Fraud Detection Using Digital Analysis. The EDP Audit, Control, and Security Newsletter 27:3

[7]. Ekiran, O. (1999). Basic Understanding of Capital Market Operations. Imprint: Lagos

[8]. Igwe, J. U. K. (2004). Global Perspective on Capital Market Laws and Regulations. Seminar Paper Presented at a National Workshop organized by SEC at SEC Training School, Abuja.

[9]. Larson, P. (2004). Development in the Regulation of Economic Crime in Norway. Journal of Financial Crime 13(1) 
[10]. Millard, G.H. (2005). Business of Crime. The Enterprise of Crime and Terror - the Implications for Good Business. Seminar Paper Presented at the XXXIII International Symposium on Economic Crime, Jesus College Cambridge.

[11]. Mwenda, A. (2006). Foreign Aid and the Weakening of Democratic Accountability in Uganda. Foreign Policy Brief No. 88. CATO Institute: Uganda

[12]. Quinney, R. (1980). Class, State, and Crime. Second Edition. New York: Longman Publishers.

[13]. Reid, S.T. (1996). Crime and Criminology. USA: Brown \& Benchmark Publishers.

[14]. Shehu, A. Y. (2006): Economic and financial Crimes in Nigeria: Policy Issues and Options. Lagos: Express Image.

[15]. Siegel, L. J. (2004). Criminology: Theories, Pattern and Typologies. USA: Wadsworth, a Division of Thompson Learning Inc.

[16]. Simpson, S.S. (2001). Corporate Crime, Law, and Social Control. Cambridge university press.

[17]. Snider, L (1993). Bad Business: Corporate Crime in Canada, Toronto: Nelson.

[18]. Tappan, Paul. 1947. "Who is the Criminal?" In Stuart Henry and Mark Lanier (eds.), what is Crime? New York: Rowman and Littlefield Publishers, Inc., pp. 27-36 http://en.wikipedia.org/wiki/corporatecrime 